\title{
Hemşirelik Öğrencileri İçin Çocuklarda İlaç Uygulamaları Öz-Yeterlilik Ölçeği’nin Geliştirilmesi ve Psikometrik Özellikleri
}

\author{
İlknur BEKTAŞ ${ }^{1}$, (iD) Figen YARDIMCI ${ }^{2}$, (iD) Murat BEKTAŞ ${ }^{3}$
}

'Öğr. Gör. Dr., Dokuz Eylül Üniversitesi Hemşirelik Fakültesi Çocuk Sağlı̆̆ı ve Hastalıkları Hemşireliği Anabilim Dalı, İzmir, Türkiye. ${ }^{2}$ Doç. Dr., Ege Üniversitesi Hemşirelik Fakültesi Çocuk Sağlığı ve Hastalıkları Hemşireliği Anabilim Dalı, İzmir. Türkiye.

${ }^{3}$ Prof. Dr., Dokuz Eylül Üniversitesi Hemşirelik Fakültesi Çocuk Sağlığı ve Hastalıkları Hemşireliği Anabilim Dalı, İzmir, Türkiye.

\section{$\ddot{\mathbf{O} z}$}

Giriş: İlaç uygulamaları hemşirelik eğitiminin en temel becerisidir. Literatürde çocuklarda ilaç uygulamalarına ilişkin hemşirelik öğrencilerinin öz-yeterliliklerini değerlendiren ölçekler yeterli değildir. Amaç: Bu araştırma "Hemşirelik Öğrencileri İçin Çocuklarda İlaç Uygulamaları Öz-Yeterlilik Ölçeği”nin geliştirilmesi ve psikometrik özelliklerinin incelenmesi amacıyla yapılmıștır. Yöntem: Metodolojik tipte olan bu çalışma Mart-Nisan 2021 tarihlerinde, 3. ve 4. sınıf hemşirelik öğrencileri ile yürütülmüştür. Araştırmaya 209 hemşirelik öğrencisi dahil edilmiştir. Araştırmada "Öğrenci Tanıtıcı Bilgi Formu” ve "Hemşirelik Öğrencileri İçin Çocuklarda İlaç Uygulamaları Öz-Yeterlilik Ölçeği” kullanılmıştır. Tanımlayıcı verilerin analizi sayı, yüzde ve ortalamalar, ölçeğin psikometrik analizinde kapsam geçerliliği, açıklayıcı ve doğrulayıcı faktör analizi Cronbach $\alpha$, madde toplam korelasyonu, iki yarıya bölme ve test-tekrar test analizleri kullanılmıştır. Bulgular: Ölçek 16 madde ve 2 alt boyuttan oluşmuştur. Ölçeğin tümü için Cronbach alfa katsayısı .94, birinci ilaç hazırlama alt boyutu için .91 ve ikinci ilaç uygulama alt boyutu için .87 olarak saptanmıştır. Ölçek toplam varyansın \%52.7'sini açıklamaktadır. Birinci alt boyutu toplam varyansın \% 26.4'ini, ikinci alt boyutu \% 26.7'unu, açıklamaktadır. Yapılan doğrulayıcı faktör analizi sonucunda uyum İndeksleri .90 'dan büyük, RMSEA .08'den küçük diğer uyum indeksleri .80 'den büyük bulunmuştur. Sonuç: Geliştirilen ve Türkçe psikometrik özellikleri incelenen "Hemşirelik Öğrencileri İçin Çocuklarda İlaç Uygulamaları Öz-Yeterlilik Ölçeği” geçerli ve güvenilir bir ölçme aracıdır. Bu ölçme aracıyla hemşirelik öğrencilerinin çocuklarda ilaç uygulamalarına yönelik öz-yeterlilikleri değerlendirilebilir, farklı eğitim yöntemleriyle öğrencilerin çocuklarda ilaç uygulamalarına yönelik öz yeterlilikleri geliştirilebilir.

Anahtar Sözcükler: Hemşirelik Öğrencisi, İlaç Uygulama, Öz-yeterlilik, Geçerlilik, Güvenilirlik.

\section{Abstract \\ Development of Medication Adminstration Self-Efficacy Scale in Children for Nursing Students and Psychometric Properties s}

Backround: Medication adminstration are the most fundamental subjects of nursing education. In the literature, scales evaluating the self-efficacy of nursing students regarding drug administration in children are not sufficient. Objectives: This study was conducted to develop the Self-Efficacy Scale for Nursing Students in Medication Adminstration in Children and to examine the psychometric properties. Methods: This methodological study was carried out with 3rd and 4th year nursing students between March-April 2021. The study were included 209 nursing students. The "Student Introductory Information Form" and the "Medication Adminstration Self-Efficacy Scale in Children for Nursing Students" were used in the study. Data analysis, content validity of the scale for psychometric studies, explanatory and confirmatory factor analysis Cronbach $\alpha$, item total correlation, split-half and test-retest analyzes were used. Results: The scale consists of 16 items and 2 subdimensions. The Cronbach alpha coefficient was .94 for the whole scale, .91 for the first drug preparation sub-dimension and .87 for the second drug administration sub-dimension. The scale explains $52.7 \%$ of the total variance. The first sub-dimension explains $26.4 \%$ of the total variance, and the second sub-dimension explains $26.7 \%$. As a result of the confirmatory factor analysis, fit indices were found to be greater than .90 , and other fit indices were found to be greater than .80, RMSEA less than .08. Conclusion: The "Medication Adminstration Self-Efficacy Scale in Children for Nursing Students", which has been developed and whose Turkish psychometric properties are examined, is a valid and reliable measurement tool. With this measurement tool, the self-efficacy of nursing students for drug administration in children can be evaluated, and students' self-efficacy for medication administration in children can be improved with different education methods.

Key Words: Nursing Student, Medication Administration, Self-efficacy, Scale Validity, Reliability.

\section{Geliş Tarihi / Received: 13.04.2021 Kabul Tarihi / Accepted: 28.06.2021}

Correspondence Author: Öğr. Gör. Dr., Dokuz Eylül Üniversitesi Hemşirelik Fakültesi Çocuk Sağlığı ve Hastalıkları Hemşireliği Anabilim Dalı, İzmir, Türkiye. E-posta: ilknurbektas23@gmail.com.

Cite This Article: Bektaşi İ, Yardımcı G, Bektaş, M. Hemşirelik Öğrencileri İçin Çocuklarda İlaç Uygulamaları Öz-Yeterlilik Ölçeği’nin Geliştirilmesi ve Psikometrik Özellikleri. Dokuz Eylül Üniversitesi Hemşirelik Fakültesi Elektronik Dergisi. 2021; 14(4): 320- 327 
I laç uygulamaları hemşirelik girişimlerinin en önemli bölümünü oluşturur. Tedavi sürecinde istemi yapılan bir ilacın doğru hazırlanması, doğru hastaya uygun şekilde uygulanması ve etkisinin değerlendirilmesinde en büyük sorumluluk hemşirelerindir (1). Hasta güvenliği kapsamında hatalı uygulamaların büyük bir kısmını da hatalı ilaç uygulamaları oluşturmaktadır (2). Bu durum hemşirelerin ilaç uygulamalarındaki sorumluluğunu arttırmakta ve bu alanda daha donanımlı olmalarını zorunlu hale getirmektedir. İlaç uygulamaları hemşirelik eğitiminde de en temel becerilerden biridir (3-5). Hemşirelik eğitiminin her aşamasında öğrencilere, doğru ilaç uygulama ilkelerini öğretmek, bilgi ve becerilerini geliştirmek için çeşitli yöntemler kullanılmakta ve yeterliliklerinin arttırılması hedeflenmektedir (35). Öğrenciler ilaç uygulamalarını öncelikle teorik olarak öğrenmekte; laboratuvarlarda uygulama becerilerini geliştirmekte ancak bu becerilerini klinikte sınırlı ve kontrollü şekilde uygulamalarına izin verilmektedir. Bu nedenle teorik olarak yeterli bilgileri olsa da öğrencilerin ilaç uygulama becerilerinin geliştirilmesi için özel hasta gruplarına ve riskli ilaçlara yönelik yeterliliklerinin arttırılması büyük önem taşır $(6,7)$. Çocuklarda farklı yaş grupları, anatomik ve fizyolojik özellikleri, pediatrik dozlar için hesaplama gerekmesi, çocuklarda ilaç uygulamalarına yönelik hemşirelik öğrencilerinin desteklenmelerini zorunlu hale getirmektedir $(8,9)$. İlaç uygulamalarında sınırlı deneyimleri olan hemşirelik öğrencileri çocuklarda ilaç uygulamalarında hata yapma korkusunu daha belirgin yaşamaktadır $(10,11)$. Öğrencilerin yaşadığı hata yapma korkusu öğrendiği becerilerin uygulanmasında da öğrencilerin öz yeterliliğini düşürmektedir. Çünkü öz yeterlilik kişinin bir davranışı gerçekleştirebilmesine ilişkin kendine olan güvenidir (12). Dinamik bir kavram olan öz yeterlilik, bir beceriye ilişkin kişinin performansının zamanla değişebileceğini yansıtmaktadır (12). Öz yeterlilik davranış ve becerilerin sürdürülmesinde kullanılan önemli bir kavramdır. Sık deneyimlenen ve olumlu sonuçlanan uygulamalar için öz yeterlilik artarken; yeterli deneyimlenemeyen beceriler için azalmaktadır.

Çocuklarda ilaç uygulamaları hemşirelik öğrencilerinin sık uygulama yapabildikleri bir alan değildir. Çocuk kliniklerinde öğrencilerin ilaç uygulamalarına yönelik daha çok gözlem yaptığı, ilaçların hazırlanma aşamasında hesaplama, doğru ilaç dozunu elde etmek için hemşire ve öğretim elemanları ile teorik tartışma yaptıkları bilinmektedir. Literatürde öğrencilerin çocuklarda ilaç uygulama becerileri için teknoloji destekli ve simülasyona dayalı eğitimlerle yeterliliklerinin arttırılabildiği görülmektedir $(13,14)$. Öğrencilerin özel bir alanda kendi yeterliliklerini değerlendirmeleri, başarılı olmaya yönelik algıladıkları öz yeterlilikleri; kendi kendine öğrenme, ihtiyaç duyduğu bilgi ve becerilerin farkında olmasını ve yaşam boyu öğrenme becerilerinin gelişimine katkı sağlar. Literatürde hemşirelik öğrencilerinin ilaç uygulamalarına yönelik yeterliliklerini değerlendiren çalışmalar bulunmaktadır (6,15-17). Ancak çocuklarda ilaç uygulamaları ile ilgili çalışmalar genellikle hesaplamalar ve hatalı uygulamalar ile ilgilidir $(8,10,11)$. Hemşirelik öğrencilerinin çocuklarda ilaç uygulamalarına ilişkin öz yeterlilik düzeyleri yeterince araştırılmamıştır. Bu araştırma; "Hemşirelik Öğrencileri İçin Çocuklarda İlaç Uygulamaları Öz-Yeterlilik Ölçeği’nin Geliştirilmesi ve Psikometrik Özellikleri”nin incelenmesi amacıyla yapılmıştır.

\section{Araştırmanın Tipi}

Yöntem

Metodolojik tipte olan bu çalışma hemşirelik öğrencileri ile Mart-Nisan 2021 tarihlerinde yürütülmüştür.

\section{Araştırmanın Yapıldı̆̆ Yer}

Araştırma Türkiye'nin batısında bulunan bir üniversitenin hemşirelik fakültesinde öğrenim gören öğrencileri ile yürütülmüş̧ür.

\section{Araştırmanin Evren ve Örneklemi}

Araştırmanın evrenini araştırmanın yapıldığı üniversitenin hemşirelik fakültesinde öğrenim gören tüm öğrenciler oluşturmaktadır. Gelişigüzel örneklem yöntemi ile veriler Mart-Nisan 2021 tarihleri arasında toplanmıştır. Araştırmanın örneklemini üçüncü sınıftaki tüm öğrenciler ile dördüncü sınıf pediatri hemşireliği intörlük eğitimi alan hemşirelik öğrencileri oluşturmuştur. Çalışmanın yapıldığı fakültede üçüncü sınıfta 275 öğrenci ve dördüncü sınıf pediatri hemşireliği imtörnlük eğitimi alan 29 hemşirelik öğrencisi olmak üzere toplamda 304 öğrenci bulunmaktadır. Çalışmanın yapıldığı fakültede üçüncü sınıf Çocuk Sağlığı ve Hastalıkları Hemşireliği dersi güz döneminde ve dördüncü sınıf pediatri hemşireliği intörnlük dersi her iki dönemde verilmektedir. Veriler pandemi nedeniyle uzaktan eğitim sürecinde olan hemşirelik öğrencilerinden Çocuk Sağlığı ve Hastalıkları Hemşireliği Dersi ile Hemşirelikte Bakım Yönetimi dersleri sürecinde online toplanmıştır. Araştırmanın yürütüldüğü üniversitenin 4. sınıfında öğrenciler 8 anabilim dalı şeklinde şubelere ayrılarak teorik eğitimlerini sürdürmüşlerdir. Araştırmaya dahil edilme kriterleri Çocuk Sağlığı ve Hastalıkları Hemşireliği dersi ve intörnlük programında eğitim almak, araştırmaya katılmayı gönüllü olarak kabul etmektir. Literatürde ölçme araçlarının geçerlilik ve güvenilirlik çalışmalarında örneklem büyüklüğü hesaplanırken ölçekte bulunan madde sayısının 5-10 katı sayıdaki örnekleme ulaşılması gerektiği belirtilmektedir (1823). $\mathrm{Bu}$ ölçme aracında madde havuzunda bulunan 31 madde nedeniyle 155-310 hemşirelik öğrencisine ulaşmak hedeflenmiş̧tir. Araştırmaya katılmayı gönüllü olarak kabul eden 209 öğrenci çalışmanın örneklemini oluşturmuştur. Örnekleme ulaşma oranı \% 68.8'dir.

Araştırma ölçek maddeleri için literatür doğrultusunda madde havuzunun oluşturulması, ölçeğin taslak halinin oluşturulması ve uzman görüşünün alınması, ölçeğin ön uygulamasının yapılması, verilerin toplanması ve analizi adımlarından oluşmuştur.

\section{Madde Havuzunun Oluşturulması}

Madde havuzu oluşturulmasında Türkiye'de ve yurt dışında geliştirilmiş ölçekler, ilaç uygulamasıyla ilgili teorik bilgiler 
ve özyeterlilik kavramları ayrıntılı olarak incelenmiş̧ir. Madde havuzu daha önce özyeterlilik çalışış, pediatri hemşireliği alanı ile ölçek geliştirme alanında deneyimli olan kıdemli bir araştırmacının danışmanlığında oluşturulmuştur. Ölçeğin maddelerinin oluşturulması literatürde hemşirelik öğrencilerinin çocuklarda ilaç uygulamalarına hazırlama, gereken matematiksel işlemleri yapabilme, uygun bölge ve veriliş yolunun seçilmesi, yetişkin dozundan pediatrik doz elde edebilme gibi becerilerin araştırıldığ çalışmalar doğrultusunda Bandura'nın özyeterlilik kavramı temel alınarak hazırlandı (8-14,23-31). Araştırmacılar ölçek maddelerini literatürden yararlanarak pediatri hemşirelerinin çocuklarda ağrı yönetiminde engelleri ve güçlük yaşadıkları alanlara ilişkin ifadeler ile oluşturmuştur.

\section{Veri Toplama Araçları}

\section{Öğrenci Tanitıcı Bilgi Formu}

Öğrencilerin yaş, cinsiyet, sınıf, çocuklarda ilaç uygulamaları ile ilgili ders dışında bir eğitim alma durumları, çocuklarda ilaç uygulamalarına ilişkin kendilerini ne kadar yerli buldukları ile ilgili soruları içermektedir. Bu form araştırmacilar tarafindan oluşturulmuştur.

Hemşirelik Öğrencileri İçin Çocuklarda İlaç Uygulamaları Öz-Yeterlilik Ölçeği

Ölçek araştırmacılar tarafindan pediatrik ilaç uygulama rehberleri ve literatürde hemşirelik öğrencilerinin çocuklarda ilaç uygulamalarıyla ilgili yapılan çalışmalar doğrultusunda geliştirilmiştir $(8-14,30,31)$. Ölçek maddeleri çocuklarda farklı yaş gruplarında ilaçların hazırlanması, doğru ilaç uygulamaları, hekim istemine uygun doğru dozda ilacın hazırlanması, doğru sulandırma, kuru toz hacmi, ilaç uygulamalarında çocuğun ve aile bireylerinin işleme hazırlanması ile ilgilidir. Ölçek geliştirilirken 35 madde olarak geliştirilmiş uzman görüşleri doğrultusunda benzer ifadeleri içeren 4 madde ölçekten çıkartılmıştır. 31 maddeli ölçek 209 hemşirelik öğrencisine uygulanmış, faktör yükü .50'nin altında kalan 15 madde madde ölçekten çıkarılmıştır. Ölçek 16 madde ve iki alt boyuttan oluşmaktadır. 5'li likert tipinde ve 1=Kesinlikle yeterli değilim, 2=Biraz yeterliyim, $3=$ Kısmen Yeterliyim, $4=$ Yeterliyim, $5=$ Kesinlikle Yeterliyim şeklindedir. Ölçekten alınan en düşük puan 16 en yüksek puan 80'dir. Ölçeğin kesme noktası yoktur puan yükseldikçe öğrencilerin pediatrik ilaç uygulamalarına ilişkin öz-yeterlilikleri yükselmektedir. Ölçeğin ters puanlanan maddesi bulunmamaktadır. Ölçeğin geçerlilik ve güvenilirlik sonuçları bulgular kısmında verilmiştir.

\section{Verilerin Toplanmast}

Çalışmada veriler iki aşamada toplanmıştır. Birinci aşamada pilot uygulama ve ikinci aşamada geçerlik-güvenirlik çalışması yapılmıştır. Birinci aşamada, ölçekte yer alan soruların anlaşılırlığı, dil bilgisi ve doldurma aşamasında sorun yaşanıp yaşanmadığı ile ilgili 20 öğrenci ile pilot uygulama yapılmıştır. Pilot uygulama sonucunda soruların anlaşılır olduğu ve olumsuz bir geri bildirim olmadığı saptanmıştır. Pilot uygulama verileri ikinci aşamadaki geçerlilik ve güvenilirlik analizlerine dahil edilmemiştir. İkinci aşamada verilerin elektronik ortamda toplanması için Google form oluşturulmuştur. Fakülte tarafından google formlar öğrencilerin emaillerine ve derste iletişim kurmak için oluşturdukları mesajlaşma programı aracıllğı ile öğrencilere gönderilmiş, öğrencilere araştırma hakkında bilgi verilmiş ve vermiş oldukları yanıtların akademik başarılarına bir etkisinin olmadığı belirtilmiştir. Çalışmaya katılmayı kabul eden 209 öğrenci formları doldurmuştur.

\section{Kapsam Geçerliliği}

Oluşturulan 35 maddelik madde havuzu çocuklarda ilaç uygulamalarına yönelik çalışmaları bulunan akademisyen ve klinik hemşirelerden oluşan uzman kişilere gönderildi. Uzmanların önerileri doğrultusunda 4 madde benzer kavramları ölçtüğü için madde havuzundan çıkarıldı uzmanlar arasındaki uyum .99 olarak saptandı.

\section{Pilot uygulama (Ön Uygulama)}

Uzman görüşleri ve dil uzmanının görüşleri doğrultusunda ölçeğin 31 maddelik taslak formu ile 20 öğrenciye ön uygulama yapıldı ve anlaşılmayan bir maddenin olmadığı görüldü. Öğrenciler ölçek maddelerini google.forms aracılığı ile doldurdular. Pilot uygulamadan elde edilen veriler ve çalışmaya katılan öğrencilerin geçerlilik ve güvenilirlik çalışmasına dahil edilmedi.

\section{Verilerinin Değerlendirilmesi}

Verilerin değerlendirilmesinde IBM SPSS 24.0 ve AMOS 24.0 programları kullanılmıştır. Tanımlayıcı verilerin değerlendirilmesinde sayı, yüzde ve ortalama kullanılmıştır. Güvenirlik analizi için Cronbach alfa, madde-toplam puan analizi, iki yarıya bölme analizi ve test-tekrar test analizleri kullanılmıştır. Test-tekrar test dört hafta ara ile yapılmıştır. Verilerin eşleştirilmesinde araştırmacılar tarafından yönerge doğrultusunda oluşturulan rumuz kullanılmıştır. Ölçeğin toplanabilir olup olmadığı Tukey toplanabilirlik testi ile ve tepki yanlılığı Hotelling $T^{2}$ testi ile değerlendirilmiştir. Geçerlilik için madde ve ölçek bazında kapsam geçerlik indeksleri, açıklayıcı faktör analizi ve doğrulayıcı faktör analizi kullanılmıştır. Anlamlılık düzeyi .05 kabul edilmişsir.

\section{Araştırmanin Etik Yönü}

Araştırma sürecinde öğrencilerin eğitim aldıkları hemşirelik fakültesi dekanlığından yazılı kurum izni alınmıştır. Üniversitenin Girişimsel Olmayan Klinik Araştırmalar Etik Kurul'undan 08.03.2021 tarih ve 2021/08-16 karar numarası ile Etik Kurul İzni alınmıştır. Veri toplama sürecinde öğrencilere google.form aracılığ ile araştırma hakkında bilgi verilmiş ve "Araştırmaya Katılmayı Kabul Ediyorum" sekmesi ile onamları alınmıştır. Makalenin tüm basamaklarında araştırma ve yayın etiği ilkelerine uygun davranılmıştır.

\section{Örneklem Özellikleri}

\section{Bulgular}

Araştırmaya katılan öğrencilerin yaş ortalamaları $21,44 \pm 1.14$ ve \%70'i $(n=147)$ kız öğrenci ve \%62'si $(n=131)$ üçüncü sınıftır. Öğrencilerin \%77,5 $(\mathrm{n}=162)$ ders kapsamı dışında pediyatrik ilaç uygulamaları ile ilgili herhangi kurs/sempozyum/eğitime katılmamıştır. Öğrencilerin \%51.2'si $(\mathrm{n}=107)$ çocuklarda ilaç uygulamalarına ilişkin orta derecede endişeli olduğunu ve \%60,8'si $(n=127)$ çocuk sağlığ ve hastalıkları eğitimi için istekli olduğunu bildirmiştir. 


\section{Kapsam Geçerliliği}

Ölçeğin kapsam geçerliliğini belirlemek için 6 uzmandan görüş alınmıştır. Uzmanlar arasındaki uyum kapsam geçerlilik indeksi ile hesaplanmıştır. Madde bazında kapsam geçerlik indeksinin .92 ile .99 arasında, ölçek bazında kapsam geçerlilik indeksinin ise .98 olduğu belirlenmiştir.

\section{Açıklayıcı Faktör Analizi}

Açıklayıcı faktör analizi sonucunda Kaiser-Meyer Olkin (KMO) kat sayısı .934, the Bartlett $X^{2}$ testi 1911.276 ve $p<$ .001 olarak saptanmıştır. AFA sonucunda ölçeğin iki alt boyuttan oluştuğu, iki alt boyutun toplam varyansın \% 52.7 'sini açıkladığı belirlenmiştir. Birinci alt boyutun faktör yüklerinin .47 ile .77 arasında ve ikinci alt boyutun faktör yüklerinin .44 ile .68 arasında değiştiği saptanmıştır. (Tablo 1).

Tablo 1. Açıklayıcı Faktör Analiz Sonucu $(n=209)$

\begin{tabular}{lccccc}
\hline Ölçek & Faktör Yükleri & $\begin{array}{c}\text { Alt Boyutlar } \\
\text { tarafindan } \\
\text { açıklanan varyans }\end{array}$ & $\begin{array}{c}\text { Açıklanan } \\
\text { Toplam } \\
\text { Varyans }\end{array}$ & KMO* & $\begin{array}{l}\text { Bartlett } X^{2} \text { Testi } \\
\mathrm{p}^{* *}\end{array}$ \\
\hline Tüm Ölçek & $.67-.80$ & & $52.7 \%$ & .934 & 1911.276 \\
Birinci Alt boyut & $.31-.88$ & 26.4 & & .001 \\
İkinci Alt Boyut & $.38-.74$ & 26.7 & & \\
\hline
\end{tabular}

*KMO=Kaise Meyer Olkim, ${ }^{* *} \mathrm{p}=$ anlamlllık düzeyi

\section{Doğrulayıcı Faktör Analizi}

Doğrulayıc faktör analiz sonucuna göre $X^{2}=196.195, d f=98, \mathrm{X}^{2} / d f=2.002$, RMSEA $=.069, \mathrm{GFI}=.90, \mathrm{CFI}=.95$, $\mathrm{TLI}=.94, \mathrm{NFI}=.90, \mathrm{IFI}=.95, \mathrm{RFI}=.88$ olarak saptanmıştır $($ Tablo 2$)$. DFA göre birinci alt boyutun faktör yükleri .68 ile .83 arasında, ikinci alt boyutun faktör yükleri .60 ile .74 arasında değiştiği saptanmıştır (Şekil 1, Tablo 2).

Tablo 2. Doğrulayıcı Faktör Analizi Sonucu (n=209)

\begin{tabular}{lllllllllll}
\hline & $\mathrm{X}^{2}$ & $\mathrm{DF}^{\mathrm{a}}$ & $\mathrm{X}^{2} / \mathrm{DF}$ & $\mathrm{RMSEA}^{\mathrm{b}}$ & $\mathrm{GFI}^{\mathrm{c}}$ & $\mathrm{CFI}^{\mathrm{d}}$ & $\mathrm{IFI}^{\mathrm{e}}$ & $\mathrm{RFI}^{\mathrm{f}}$ & $\mathrm{NFI}^{\mathrm{g}}$ & $\mathrm{TLI}^{\mathrm{h}}$ \\
\hline $\begin{array}{l}\text { İki } \\
\text { boyutlu }\end{array}$ & 196.195 & 98 & 2.002 & .069 & .90 & .95 & .95 & .88 & .90 & .94
\end{tabular}

boyutlu

model

a=Degree of Free (Serbestlik derecesi); b=Root Mean Square Error of Approximation (Yaklaşık hataların ortalama karekökü; $\mathrm{c}=$ Goodness of Fit Index (Uyum iyiliği indeksi); d=Comparative Fit Index (Karşılaştırmalı uyum İndeksi); e=Incremental Fit Index (Fazlalık uyum indeksi); f=Relative Fit Index (Göreli uyum indeksi); g=Normed Fit Index (Normlaştırılmış uyum indeksi); TLI=Trucker-lewis Index (Normalleştirilmemiş uyum indeksi).

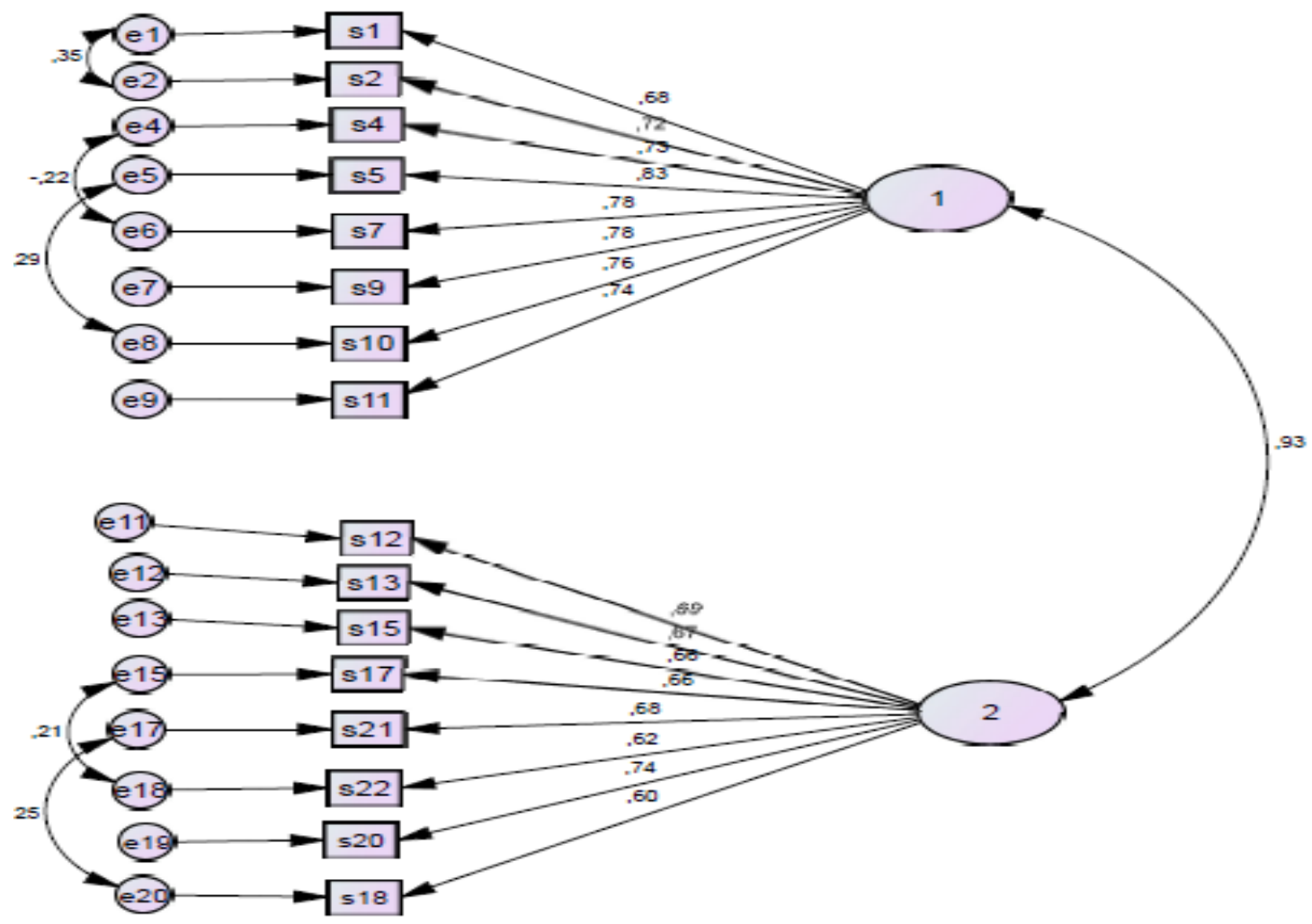

Şekil 1. Doğrulayıcı Faktör Analizi

Dokuz Eylül Üniversitesi Hemşirelik Fakültesi Elektronik Dergisi 
Ölçeğin tümü için Cronbach alfa katsayısı .94, birinci ilaç hazırlama alt boyutu için .91 ve ikinci ilaç uygulama alt boyut için .87 olarak saptanmıştır. Ölçeğin kompozit güvenirliği birinci alt boyut için .91 ve ikinci alt boyut için .86 olarak belirlenmiştir. Yapılan iki yarıya bölme analizi sonucunda birinci yarının Cronbach alfa .88 ve ikinci yarının Cronbach alfa değeri .89 olarak belirlenmiştir. Analiz sonucunda Spearmen Brown kat sayısı .93, Guttman-split-half kat sayısı .93 ve iki yarı arasındaki korelasyon .87 olarak saptanmıştır. Ölçekte taban ve tavan etkinin olmadığı saptanmıştır. Ölçeğin toplanabilir olup olmadığı Tukey toplanabilirlik testi ile değerlendirilmiş olup, non-additivity F değeri 2.337 ve p değeri 126 olarak saptanmıştır. Tukey toplanabilirlik analizi sonucu ölçeğin toplanabilir nitelikte olduğu belirlenmiştir. Ölçekte tepki yanlılığı olup olmadığ 1 Hotelling T2 testi ile incelenmiş olup, Hotelling T2 değeri $618.659, \mathrm{~F}=38.468$ ve $\mathrm{p}<.01$ olarak saptanmıştır (Tablo 3). Analiz sonucunda ölçekte tepki yanlılığ́ olmadığ1 belirlenmiştir. Ölçek madde toplam puan korelasyonunun .60 ile .77 arasında ve madde-alt ölçek toplam puanları arasındaki korelasyonun .59 ile .77 arasında değiştiği saptanmıştır (Tablo 3).

\section{Test-Tekrar Test Analizi}

Yapılan test-tekrar test analiz sonucunda ölçeğin birinci ve ikinci uygulama ölçek toplam ve alt boyut toplam puanları arasında istatistiksel olarak anlamlı bir farkın olmadığı saptanmıştır ( $\mathrm{p}>.05)$. Birinci ve ikinci uygulama ölçek toplam ve alt boyut toplam puanları arasında pozitif yönde, çok güçlü ve anlamlı bir ilişki olduğu saptanmıştır $(\mathrm{p}<.005)$ (Tablo 4).

Tablo 3. Ölçek ve alt boyutların güvenirlik analiz sonuçları $(n=209)$

\begin{tabular}{|c|c|c|c|c|c|c|c|c|c|c|c|c|}
\hline \multirow{2}{*}{$\begin{array}{l}\text { Ölçek ve } \\
\text { alt ölçekler }\end{array}$} & \multicolumn{2}{|c|}{ Cronbach Kompozit } & \multicolumn{5}{|c|}{ İki Yarıya Bölme Analizi } & \multirow[b]{2}{*}{$\begin{array}{l}\text { Düzeltil } \\
\text { miş } \\
\text { madde- } \\
\text { toplam } \\
\text { puan } \\
\text { korelasyo } \\
\text { nu } \\
\end{array}$} & \multirow[b]{2}{*}{$\begin{array}{l}\text { Düzeltilmiş } \\
\text { madde-alt } \\
\text { boyut } \\
\text { toplam } \\
\text { puan } \\
\text { korelasyonu }\end{array}$} & \multirow[t]{2}{*}{$\mathrm{X}^{*} \pm \mathrm{SS}^{* *}$} & \multirow{2}{*}{$\begin{array}{c}\text { Taba } \\
\text { n } \\
\text { Etki } \\
\%\end{array}$} & \multirow{2}{*}{$\begin{array}{c}\text { Tavan } \\
\text { Etki } \\
\%\end{array}$} \\
\hline & $\alpha$ & $\begin{array}{l}\text { Güvenirl } \\
\text { ik }\end{array}$ & $\begin{array}{c}\text { Birinci } \\
\text { yarı } \\
\text { Cronbach } \\
\alpha\end{array}$ & $\begin{array}{c}\text { İkinci } \\
\text { yarı } \\
\text { Cronbach } \\
\alpha\end{array}$ & $\begin{array}{l}\text { Spearm } \\
\text { an- } \\
\text { Brown }\end{array}$ & $\begin{array}{l}\text { Guttm } \\
\text { an } \\
\text { split- } \\
\text { half }\end{array}$ & $\begin{array}{r}\text { İki yarı } \\
\text { arası } \\
\text { ndaki } \\
\text { korel } \\
\text { asyon }\end{array}$ & & & & & \\
\hline $\begin{array}{l}\text { Tüm } \\
\text { Ölçek }\end{array}$ & .94 & & .88 & .89 & .93 & .93 & .87 & $.60-.77$ & - & $\begin{array}{c}56.73 \pm \\
9.44\end{array}$ & .5 & .5 \\
\hline $\begin{array}{l}\text { 1. Alt } \\
\text { boyut }\end{array}$ & .91 & .91 & & & & & & & $.68-.77$ & $\begin{array}{c}28.15 \pm \\
5.23\end{array}$ & .5 & .5 \\
\hline $\begin{array}{l}2 . \text { Alt } \\
\text { boyut }\end{array}$ & .87 & .86 & & & & & & & $.59-.68$ & $\begin{array}{c}28.57 \pm \\
4.69\end{array}$ & 1.0 & .5 \\
\hline
\end{tabular}

*X= ölçek puan ortalamas1, ${ }^{*} \mathrm{SS}=\mathrm{Standard} \mathrm{sapma}$

Tablo 4. Test-tekrar test analiz sonucu $(n=30)$

\begin{tabular}{|c|c|c|c|c|c|c|}
\hline & $\begin{array}{c}\text { Ilk Uygulama } \\
X \pm S S\end{array}$ & $\begin{array}{c}\text { İkinci Uygulama } \\
\text { X土SS }\end{array}$ & $\mathrm{t}$ & $\mathrm{p}$ & $\mathrm{r}$ & $\mathrm{p}$ \\
\hline Toplam Ölçek & $56.06 \pm 10.87$ & $57.96 \pm 13.33$ & 1.708 & 0.098 & .893 & .000 \\
\hline Birinci Alt Boyut & $27.80 \pm 5.40$ & $28.46 \pm 5.84$ & 2.021 & 0.053 & .951 & .000 \\
\hline İkinci Alt Boyut & $28.41 \pm 5.71$ & $28.7 \pm 6.74$ & .470 & .642 & .855 & .000 \\
\hline
\end{tabular}

$\mathrm{t}=$ Bağımlı gruplrada $\mathrm{t}$ testi, $\mathrm{r}=$ Pearson korelasyon analizi, $\mathrm{p}=$ İstatistik anlamlılık düzeyi, $\mathrm{X}=$ ölçek puan ortalaması, $\mathrm{SS}=\mathrm{Standard}$ sapma

\section{Tartışma}

Araştırmanın bu bölümünde Hemşirelik Öğrencilerinin Çocuklarda İlaç Uygulamaları Öz Yeterlilik Ölçeği’nin geçerlilik ve güvenilirlik özellikleri tartışılmıştır. Ölçeğin kapsam geçerliliğini belirlemek için 6 çocuk sağlığı ve hastalıkları hemşireliği öğretim üyesi ve pediatri kliniklerinde çalışan hemşireden uzman görüş alınmıştır. Ölçme araçlarında uzman görüşleri arasında uyum olduğunu söyleyebilmek için I-CVI ve S-CVI değerinin .80’in üzerinde olması gerektiği önerilmektedir $(18,19)$. Bu ölçeğin hem madde bazında hem de ölçek bazında kapsam geçerlilik indeksinin .80'in üzerinde olduğu saptanmıştır. Bu sonuç ölçeğin konuyu yeterli olarak ölçtüğüü ve kapsam geçerliliğinin sağlandığını göstermiştir.

Verilerin faktör analizi için uygun ve yeterli sayıda olup olmadığı Barlett Sphericity test ve KMO ile değerlendirilmiştir. Literatürde faktör analizi yapılabilmesi için Barlett Sphericity test değerinin istatistiksel olarak anlamlı ve KMO değerinin en az .60 olması gerektiği vurgulanmaktadır (19-22). Bu çalışmadaki Barlett Sphericity testinin anlamlı olduğu ve KMO değerinin .60'tan büyük olduğu saptanmıştır. Bu sonuçlar örneklemin yeterli olduğunu ve korelasyon matrisinin faktör analizi için uygun olduğunu göstermektedir (19-22). Açıklayıcı faktör analizinde özdeğeri 1'den büyük olan iki faktör belirlenmiştir bunun doğrultusunda, ölçeğin iki alt boyuttan oluşmasına karar verilmiştir (22-25). İki faktörlü ölçek toplam varyansın \% 52.7'sini açıklamaktadır. Literatürde ilk defa geliştirilen çok boyutlu ölçeklerde açıklanan varyansın \%50’ı üzerinde olması önerilmektedir. Açıklanan toplam varyans ne kadar yüksekse ölçeğin o kadar güçlü bir yapı geçerliliğine sahip olduğu vurgulanmaktadır $(22,23,25)$. Bu çalışmada elde edilen toplam varyansın \%50'in üstünde olduğu, ölçeğin önerilen düzeyin üstünde açıklanan varyansa sahip olduğu belirlenmiştir. Bu sonuçlar ölçeğin yapı geçerliliğini iyi olduğunu göstermektedir.

Açıklayıcı faktör analizi sonucunda, iki alt boyuttaki maddelerin faktör yüklerinin .44-.77 arasında değiştiği saptanmıştır. Ölçeğin birinci pediatrik ilaç hazırlama alt boyutunun faktör yüklerinin .47 ile .77 ve ikinci alt boyut olan pediatrik ilaç uygulama alt boyutunun faktör yüklerinin .44 ile .68 arasında değiştiği saptanmıştır. Literatürde yeni geliştirilen ölçeklerde faktör yükü .50'nin üzerinde olan maddelerin ölçekte yer alması önerilmektedir. (19-22). Bu 
çalışmada tüm alt boyutlardaki maddelerin faktör yüklerinin .50 'den büyük olduğu belirlenmiştir. Bu sonuçlar ölçeğin güçlü bir faktör yapısına sahip olduğunu göstermiştir.

Doğrulayıcı faktör analizi sonucunda, iki alt boyutunun faktör yüklerinin .60 - .83 arasında değiştiği belirlenmiştir (Şekil 1). Tüm alt boyutlarında faktör yüklerinin .50'den büyük olduğu, uyum indekslerinin de (GFI, NFI, CFI ve IFI) .90'dan büyük, RMSEA'nin ise .080'dan küçük olduğu belirlenmiştir (Şekil 1). Ki-kare değerinin serbestlik derecesine bölümü beşten küçük bulunmuştur. Ölçek ile alt boyutları arasında güçlü ve anlamlı bir ilişki saptanmıştır (Şekil 1). Literatürde Model uyum göstergelerinin > .90, X2/DF bölümünün beşten küçük ve RMSEA'nın < .08 olmas1 iyi uyum göstergesi olarak kabul edilmektedir $(27,28)$. Bu çalışmadaki CFA sonuçları literatürde belirtilen değerlerle uyumlu bulunmuştur. CFA sonuçları verilerin modelle uyumlu olduğunu, açıklayıcı faktör analizi ile belirlenen yapıyı doğruladığını, alt boyutların ölçekle uyumlu olduğunu, maddelerin kendi alt boyutu ile yeterli düzeyde ilişkili olduğunu göstermiştir.

Cronbach alfa katsayısı, maddelerin benzer özelliği ölçüp ölçmediğini göstermektedir. Bu değer ölçeklerde homojenliğin bir göstergesidir. Yeni geliştirilen ölçeklerde ölçeğin tümü ve alt boyutları için Cronbach alfa değerinin .80 'in üzerinde olması önerilmektedir $(23,25,28,29)$. Bu çalışmada, ölçeğin toplam ve alt boyutları Cronbach alfa değerleri .90'dan büyük olduğu saptanmıştır. Bu çalışmada elde edilen Cronbah alfa değerleri, ölçeğin yüksek derecede güvenilirliğe sahip olduğunu göstermiştir. Çalışmadaki yüksek Cronbach alfa değerleri ölçekteki maddelerin hemşirelik öğrencilerinin çocuklarda ilaç uygulamalarıyla ilgili öz-yeterliliğini ölçtüğünü, maddelerin birbiriyle ilişkili olduğunu, ölçeğin yüksek düzeyde güvenirliğe sahip olduğunu göstermiştir $(23,25,28,29)$.

Bu çalışmada iç tutuarlılığı belirlemek için kullanılan diğer bir yöntem iki yarıya bölme yöntemidir. Literatürde iki yarı arasında en az .70 düzeyinde bir korelasyonun olması her iki yarının Cronbach alfa değerlerinin .70'in üzerinde olması, Spearman-Brown ve Guttman Split-Half katsayılarının .80'in üzerinde olması önerilmektedir $(23,25,28,29)$. Çalışmamızdaki iki yarıya bölme sonuçları literatürün önerdiği sınırların oldukça üzerinde olduğu saptanmıştır. Bu sonuçlar ölçeğin yüksek düzeyde güvenirliğe sahip olduğunu göstermiştir.

Madde-toplam puan analizi, ölçekteki maddelerin ölçülmek istenen kavramı ölçüp ölçmediğinin bir göstergesidir $(23,25,28,29)$. Madde-toplam puan korelasyonunun en az .30 olması önerilmektedir (23,24). Bu çalışmada, maddelerin hem ölçek toplam puanı hem de alt boyut toplam puanı ile korelasyonlarının .30'den büyük olduğu bulunmuştur. Bu çalışma sonuçları maddelerinin hem ölçekle hem de alt boyut ile ilişkili olduğunu, maddelerin hemşirelik öğrencilerinin çocuklarda ilaç uygulamalarına ilişkin öz yeterliliklerini yeterli düzeyde ölçtüğü, ölçekteki maddelerin güvenilirliğinin yüksek olduğunu göstermiştir.

Literatürde ölçeklerin güvenirliğini ve geçerliliğini sınama da kullanılması önerilen yöntemlerden biri de \%27'lik üst-alt grup karşılaştırılmasıdır $(23,25,28,29)$. Bu çalışmada \%27'lik üst grupta kalan öğrenciler ile \%27'lik alt grupta kalan öğrencilerin ölçek toplam puan ortalamaları arasında istatistiksel olarak anlamlı bir fark saptanmıştır (p $<$.005). Bu sonuçlar ölçeğin iyi bir ayrım gücüne sahip olduğunu, ölçmek istenilen alanı yeterli kadar ölçebildiğini, \%27'lik üst-alt grupları birbirinden ayırabildiğini göstermektedir. Bu sonuç öğrencilerin çocuklarda ilaç uygulamalarına ilişkin öz yeterliliğini ölçmede kullanılabilecek geçerli ve güvenilir bir ölçek olduğunu göstermektedir.

Literatürde ölçüm araçlarının değişmezliğini kanıtlamada önerilen analizlerden biri test-tekrar test anallizidir. $\mathrm{Bu}$ analizde birinci uygulama toplam puanı ile ikinci uygulama toplam puanı arasında istatistiksel olarak anlamlı bir farkın olmaması beklinir. Aynı zamanda da iki ölçüm arsındaki korelasyonun mümkün olduğunca biri yakın olması beklenir (19-22). Bu çalışmada da iki uygulama toplam puanları arasında istatistiksel olarak anlamlı bir fark saptanmazken $(\mathrm{p}>$.005), iki ölçüm arasında pozitif yönde, güçlü ve anlamlı bir ilişki saptanmıştır $(\mathrm{p}<.005)$. Bu sonuçlar ölçeğin iç tutarlılığının yüksek olduğu, ölçeğin ölçmeyi amaçladığg kavramı her zaman aynı şekilde ölçebildiği ve ölçeğin yüksek düzeyde güvenirliğe sahip olduğunu kanıtlamıştır.

\section{Kisıtlılıklar}

Araştırmanın birkaç sınırlılığı bulunmaktadır. Bu çalışma tek bir hemşirelik fakültesinde yürütülmüştür. Ölçme aracındaki sorular uzaktan eğitimle yürütülen teorik dersler sırasında öğrencilere google.form aracılı̆̆ı ile yönlendirilmiştir. Pediatrik ilaç uygulamalarına ilişkin öğrencilerin öz bildirimine dayalı yanıtları elde edilmiş ilaç hazırlama ve uygulama boyutları gözlenerek değerlendirilmemiştir.

\section{Sonuçların Uygulamada Kullanımı}

Araştırmada yapılan geçerlilik ve güvenilirlik analizleri sonucunda "Hemşirelik Öğrencileri İçin Çocuklarda İlaç Uygulamaları Öz-Yeterlilik Ölçeği’”nin öğrenciler için uygun bir ölçme araç olduğu belirlenmiştir. Ölçeğin farklı eğitim modellerinde öğrenim gören öğrenciler ile daha geniş örneklemde planlanan araştırmalarda kullanımı önerilir. Hemşirelik öğrencileri için çocuklarda ilaç uygulama becerilerinde öz yeterliliğin değerlendirildiği bu ölçme aracının geçerli ve güvenilir bir araç olduğu görülmektedir. Bu ölçek hemşirelik öğrencilerinin çocuk hasta grubunda ilaçların hazırlanması ve uygulanmasında öz yeterliliklerini değerlendirmek için kullanılabilir. Ayrıca öğrencilerin çocuklarda ilaç uygulamalarına yönelik yetersiz oldukları alanların belirlenmesinde kullanılabilir. Bu ölçme aracı kullanılarak hemşirelik öğrencilerinin çocuklarda ilaç uygulamalarına yönelik öz yeterliliklerini geliştirebilecek farklı eğitim yöntemleri ile deneysel çalışmalarda da kullanılması önerilir.

\section{Bilgilendirme}

Yazarların katkı oranı beyanı şöyledir: Fikir: İB, FY, MB; Tasarım: İB, FY; Denetleme: FY, MB; Veri Toplama ve İşleme: İB; Veri Analizi ve Yorumlama: İB, MB; Literatür tarama: İB, MB, FY; Makale yazma: İB, FY; Eleştirel inceleme: FY şeklindedir. Bu çalışma için 08.03.2021 tarih ve 2021/08-16 karar no ile etik kurul onayı alınmıştır. 
Araştırma için herhangi bir fon desteği alınmamış olup, çalışma metodolojik tipte araştırma türündedir ve araştırmacılar arasında çalışmaya bağlı olarak bir çıkar çatışması söz konusu değildir. Araştırmamıza veri toplama aşamasında katkılarıyla destek olan tüm hemşirelik öğrencilerine teşekkür ederiz. 


\section{Kaynaklar}

1. Elliott M, Liu Y. The nine rights of medication administration: an overview. Br J Nurs 2010;19(5),300-305.

2. Sivrikaya SK. Kara, AŞ. Hemşirelerin Tıbbi Hata Yapma Eğilimlerinin İncelenmesi. BAUN Sağ Bil Derg 2019;8(1),7-14.

3. Caner N, Kartın PT. Hemşirelerin İntramüsküler ve İntravenöz İlaç Uygulama Basamaklarının Değerlendirilmesi: Gözlem Çalışması. HUHEMFAD 2019;6(3),177-185.

4. Şendir M, Coşkun EY. Hemşirelik eğitiminde teknolojik bir adım: IMventro-sim. JAREN 2016; 2(2),103-108.

5. Jarvill M. Nursing student medication administration performance: a longitudinal assessment. Nurse Educ 2021;46(1),59-62.doi: 10.1097/NNE.0000000000000828

6. Zaybak A, Taşkıran N, Telli S, Ergin EY, Şahin M. Hemşirelik Öğrencilerinin İlaç Uygulamalarına İlişkin Bilgilerini Yeterli Bulma Durumları. JERN 2017;14(1), 6-13.

7. Sulosaari V, Kajander S, Hupli M, Huupponen R, Leino-Kilpi H. Nurse students' medication competence-An integrative review of the associated factors. Nurse Educ Today 2012;32(4),399-405.

8. Özyazıcıoğlu N, Aydın Aİ, Sürenler S, Çinar HG, Yılmaz D, Arkan B, Tunç GÇ. Evaluation of students' knowledge about paediatric dosage calculations. Nurse Educ Pract 2018;28, 34-39.

9. Kahn S, Abramson EL. Arch Dis Child 2019; 104(6), 596-599. doi:10.1136/archdischild-2018-315175

10. Akgül EA, Öztornacı BÖ, Doğan Z, Sarı HY. Determination of Senior Nursing Students' Mathematical Perception Skills and Pediatric Medication Calculation Performance. FNJN 2019;27(2),166-172.

11. Lin FY, Wu WW, Lin HR, Lee TY. The learning experiences of student nurses in pediatric medication management: A qualitative study. Nurse Educ Today 2014;34(5), 744-748.

12. Bandura A, Self-efficacy: toward a unifying theory of behavioral change, Psychological Review 84, 1977; 191-215.

13. Pauly-O'Neill S. Beyond the five rights: Improving patient safety in pediatric medication administration through simulation. Clin Simul Nurs 2009;5(5),181-186.

14. McMullan M, Jones R, Lea S. The effect of an interactive e-drug calculations package on nursing students' drug calculation ability and self-efficacy. Int J Med Inform 2011;80(6),421-430.

15. Cancino KD, Arias M, Caballero E, Escudero E. Development of a safe drug administration assessment instrument for nursing students. Rev Lat Am Enfermagem 2020;(28); e2989-e3246.

16. Arslan SAY, Ayar A, Sildir E, Çakır D. Amasya Üniversitesi Sağlık Yüksekokulu Hemşirelik Öğrencilerinin İlaç Uygulama Hataları. Düzce Üniversitesi Bilim ve Teknoloji Dergisi 2018; 6(2),481-490.

17. Chendake MB. Self-Efficacy in Drug Dosage Calculation among Undergraduate Nursing Students. Ann Med and Health Sci Res 2020;(10),882-888.

18. Polit DF, Beck, CT, Owen SV. Is the CVI an acceptable indicator of content validity? Appraisal and recommendations. Res Nurs Health. 2007;(30),459-67.

19. Terwee CB, Bot SD, de Boer MR, van der Windt DA, Knol DL, Dekker J. Quality criteria were proposed for measurement properties of health status questionnaires. J Clin Epidemiol 2007;60(1),34-42.

20. DeVellis RF. Scale Development, Theory and Applications. 3. ed. India: SAGE Publication, Inc. 2012;31-59.

21. Jonhson B, Christensen L. Educational Research: Quantitative, Qualitative, and Mixed Approaches. California: SAGE Publication, Inc.; 2014; 190-222.

22. Hayran M, Hayran M. Basic Statistic for Health Researh. 1. ed. Ankara: Art Ofset Matbacılık Yayıncılık Org. Ltd Şti. 2011;132-332.

23. Şencan H. Reliability and validity in cocial and behavioral measurement. 1.ed. Ankara: Seçkin Yayınevi. 2005.

24. Heale R, Twycross A. Validity and reliability in quantitative studies. Evid Based Nurs July, 2015;18(3),66-68.

25. Çam MO, Baysan-Arabacı L. Qualitative and quantitative steps on attitude scale construction. Hemar-G 2020;12(2),59-71.

26. Hooper D, Coughlan J, Mullen M. Evaluating model fit: a synthesis of the structural equation modelling literature. In 7th European Conference on research methodology for business and management studies, 19- 20 June 2008; London, 195-200.

27. Şimşek ÖF. Basic principles of structural equation modeling and LISREL applications. 1. ed. İstanbul: Ekinoks. 2010

28. Nunnally JC, Bernstein IH. Psychometric theory. 3. ed. New York, NY: McGraw-Hill, 2010.

29. Rattray J. Jones MC. Essential elements of questionnaire design and development. J Clin Nurs 2007;(16)234-243.

30. Hemşirelik Çekirdek Eğitim Programı $\quad$ (HUÇEP) 2014. URL:https://www.yok.gov.tr/Documents/Kurumsal/egitim_ogretim_dairesi/Ulusal-cekirdek-egitimiprogramlari/hemsirelik_cekirdek_egitim_programi.pdf. 15 Haziran 2021.

31. Hemşirelik Yönetmeliği

2011. URL:https://www.mevzuat.gov.tr/mevzuat?MevzuatNo=13830\&MevzuatTur=7\&MevzuatTertip=5.15 Haziran 2021. 